\title{
Listening to and Learning from Graduate's Perceptions: Implications for Change?
}

\author{
Vangelis Kotsifos ${ }^{1}$, Athanasios Alegakis ${ }^{2} \&$ Anastas Philalithis ${ }^{1}$ \\ ${ }^{1}$ Department of Social Medicine, Medical School, University of Crete, Greece \\ ${ }^{2}$ Laboratory of Toxicology, Medical School, University of Crete, Greece \\ Correspondence: Vangelis Kotsifos, 19, Kourmoulidon Street, 71201 Iraklion Crete, Greece. Tel: \\ 30-697-282-5475. E-mail: kotsifos@med.uoc.gr/kotsifos@gmail.com
}

\author{
Received: May 14, 2013 Accepted: June 17, $2013 \quad$ Online Published: June 24, 2013 \\ doi:10.5539/ies.v6n7p189 URL: http://dx.doi.org/10.5539/ies.v6n7p189
}

\begin{abstract}
The impact of Word of Mouth Communication (WoMC) in attracting new candidates, and thus contributing to the sustainability of Higher Education Institutions, is highlighted in the literature along with its importance as an indicator for quality improvements in course provision. In the present study graduates were questioned concerning their intention to recommend Master courses depending on satisfaction, and tracking any specific characteristics or attitudes which formulate positive or negative WoMC after graduation. A total of 162 Master graduates in Health Management, academic years of admission 2003-2007, completed satisfaction questionnaires which were developed by the authors. WoMC was recorded through the relevant questions in the same questionnaire. Demographic, vocational, educational variables and a satisfaction score based on questionnaire, were tested, in order to measure the effect on strengthening WoMC, using simple and multiple logistic regression. Graduates, who showed high overall satisfaction level of the Master Program they had attended, adopted positive WoMC recommending it to interested parties (OR: 1.11, 95\% CI: 1.05-1.17). In contrast, negative WoMC was adopted by those who were unemployed or who have been looking for work when surveyed, (OR: 0.12, 95\% CI: 0.02-0.63). It is the first time that Health Management Master graduates of Greek public institutions have been surveyed concerning the effect of satisfaction along with individual characteristics (like sex, age, marital status, first obtained degree, employment status, work consistency with degree) on their intention to recommend the Master courses in question to others. The improvement of career prospects leading to positive WoMC can both attract new students enhancing sustainability of Master courses and also offer stakeholders among others a valuable indicator concerning improvements regarding educational quality.
\end{abstract}

Keywords: Word of Mouth Communication (WoMC), master, health management, graduates, career, satisfaction, demographics, education

\section{Introduction}

The debate on course experience satisfaction, its relation with course quality, overall institutional reputation, students' recruitment and retention aspects, along with responding to participants' education and vocational needs has been ongoing over the past two decades. Several of these aspects have been thoroughly explored by both quality assessment and accreditation agents for example in Australia, UK and other countries together with independent researchers. In Greece the quality assessment procedures in Higher Education were officially amended after the establishment of the "Hellenic Assessment and Accreditation Agency" in 2005 by state law.

Public universities in Greece are to a major degree state funded. Over the last few years the number of Master courses in Greek universities on offer has risen rapidly. Nowadays their sustainability due to the additional threat of the current financial crisis is under question, and in the near future they may be challenged to support the Master courses which they independently offer. No systematic course experience satisfaction surveys on Master education have been conducted in Greece; therefore, as a part of the broader study on graduates' satisfaction currently underway, it was decided to survey their intention to recommend courses they have attended to others.

Regarding sustainability, formulating a positive Word of Mouth Communication (WoMC) as a positive oral recommendation is known in literature, and indeed a positive WoMC from graduates and alumni can be more effective than ordinary advertising techniques to recruit new candidates. «Once again the nature of education as a 
complex intangible service makes promotion via word of mouth referral and personal selling considerably more effective than conventional media advertising» (Mazzarola, Soutarb and Theina, 2001).

\subsection{Word of Mouth Communication}

Word of Mouth Communication (WoMC) can be described as the oral person to person communication from a communicator to a receiver, whom the receiver perceives as non commercial, regarding a brand, product or a service, (Arndt, 1967, Jiewanto, Laurens and Nelloh, 2012). It represents the former user's willingness to recommend a product or a service to others (Dabholkar, Thorpe, and Rentz, 1996, Jiewanto et al., 2012).

When referring to intangible services, WoMC is more influential and important than referring to products' marketing regarding the intangible nature and higher associated purchasing risk of the former (Zeithaml, 1981, Murray \& Schlacter, 1990, Murray, 1991, Bansal \& Voyer, 2000). According to previous studies, quality of a provided service seems to be antecedent of user's satisfaction (Spreng \& Markoy, 1996, Naik, Gantasala and Prabhakar, 2010, Jiewanto et al., 2012).

WoMC applies to any service provision, consequently to the highly intangible service of education. Its magnitude has been reported as equivalent to marketing communication strategies, with severe impact on potential students impressions (Ivy, 2008, Moogan, 2011).

\subsection{Word of Mouth Communication and the Higher Education Sector}

Previous studies have explored the role and the importance of WoMC in various levels and processes in the Higher Education Sector. Arambewela, Hall, and Zuhair (2006) surveyed WoMC of multi-origin students regarding studies experience satisfaction, while Mazzarola et al. (2001) in his study describes it as an important non-formal channel of advertisement and promotion of available services. Additionally, when referring to an international level, graduates who have studied in institutions abroad can operate as ambassadors to their homelands attracting future students through their WoMC (Rajab et al., 2011).

Word of Mouth Communication has been approached among others as an element of course experience or course satisfaction surveys described as word of mouth intentions which are positive or negative. When applying a more «consumerist» approach to education services, a significant parameter as an outcome of studies measuring students' satisfaction can be the positive or negative word of mouth intention and its measurement as a tool among others for the sustainability and further evolution of a course or a university. (Parasuraman, Berry, and Zeithaml, 1988, Cronin \& Taylor, 1992). Furthermore, detecting any dissatisfaction in the provision of an educational service can be of equal importance: it can help managers to formulate and implement actions for the maintenance and the improvement of its quality (Rajab et al., 2011).

Harvis and Voyer (2000) have highlighted that satisfaction is a major key to service users' retention and formulation of a positive WoMC when referring to services including education. Concerning the quality dimension of the offered curricula, Arambewela et al. (2006) emphasise that exploring procedures for the adoption of positive WoMC through students' satisfaction measurements, can help a University to maintain a competitive position and benefit from that, by improving the institutions' image and by meeting the challenge of student expectations for studies of high quality. On the other hand, students with a negative WoMC may negatively affect the image of the educational service provider resulting in a loss of custom. Summarily, it could be supported that WoMC along with past experiences and marketing activities of a HEI (Ivy, 2001, Cubillo, Sánchez, and Cerviño, 2006) formulate prospective students' opinion about the image of a HEI. Numerous studies in the context of course satisfaction survey have also highlighted the potential impact of students' positive WoMC toward friends and relatives in attracting future candidates (Guolla, 1999, Wiers-Jenssen, Stensaker, and Grogaard, 2002, Mavondo, Tsarenko, and Gabbott, 2004, C. Schertzer \& S. Schertzer, 2004, Marzo-Navarro, Pedraja-Iglesias, and Rivera-Torres, 2005a, 2005b, Helgesen \& Nesset, 2007, Gruber, Reppel, and Voss, 2010) but also, more importantly, that tracking factors leading to positive WoMC can provide guidance to HE Institutions to meet their expectations for quality studies.

Taking into account that satisfaction of graduates is a complex notion (Hartman \& Schmidt, 1995, Rhodes \& Nevill, 2004, Di Biase, 2004, Richardson, 2005, Garcia-Aracil, 2009, Kotsifos, Alegakis, and Philalithis, 2012), and the interactions between satisfaction and WoMC, the same complexity applies when investigating factors affecting WoMC of former students.As previously mentioned above, WoMC is proved to be extremely influential in the intangible service of education (Bruce \& Edgington, 2008, Moogan, 2011) thus, exploring correlations between course experience satisfaction and WoMC can provide course managers with valuable data regarding improvements on course quality, curricula content and meeting students expectations and qualification needs. In other words it is possible to use this perception of service literature as a "tool" which in combination 
with other course parameters and research findings may operate as an indicator of course perceived quality by former users.

The aim of the present article is to explore which variables affect the formulation of positive or negative WoMC among Master graduates of Greek Health Management Programmes. As a part of an extended study on Master Graduates' satisfaction, it is explored here whether course experience satisfaction or any other characteristics of graduates actually affect their intention for positive recommendation. Two questions were investigated. Firstly, do satisfied graduates from Greek Health Management Master Programs adopt positive WoMC towards the course they have attended? Secondly, if so, are there any other specific demographic, vocational or educational characteristics, attitudes or status of the graduates in question which can affect their positive or negative WoMC after graduation?

\section{Methodology}

\subsection{Population and Sample of the Survey}

The previous article focused upon satisfaction issues of graduates from three different Health Management Masters, regarding demographics (Kotsifos et al., 2012). The Masters have been organized by three Greek Public Universities, specifically the University of Crete (UoC), the National and "Kapodestrian" University of Athens (NKUA) and the University of Piraeus (UoP).

Three hundred twenty (320) Master graduates, academic years of admission 2003-2007 who had completed their studies by the time of the survey comprised the population of the study. Graduates' contact details were retrieved from each Masters' secretariat and they were reached either by e-mail message or by phone to fill the questionnaire. A total of 162 valid questionnaires were filled electronically or through phone interviewing (50.6\% response rate) by graduates.

\subsection{The Questionnaire}

The survey tool has been formulated and tested to measure satisfaction, on the basis of previous international experience on the subject and mainly based upon:

1) the British National Student Survey (NSS);

2) the Postgraduate Taught Experience Survey (PTES) of Great Britain; and

3) the Postgraduate Research Experience Questionnaire (PREQ) of Australia.

The questionnaire is divided into three parts. The first part regards demographic, occupational and educational background data. The second part consists of 36 statements, investigating studying aspects (mainly satisfaction) and the third part includes 19 questions and statements about academic development, career and employment status of participating graduates. A five point Likert scale ( $1=$ definitely disagree, $2=$ mostly disagree, $3=$ neither agree nor disagree $4=$ mostly agree, $5=$ definitely agree) is applied to declare the graduates' level of agreement on the statements of the second part and some of the statements of the third part.

The latter part of the questionnaire includes a crucial question associated with WoMC, "whether or not you would recommend the Master Program to a friend or a relative". This question is used as a dependent variable in the current research.

\subsection{Statistics and Data Analysis}

Counts and proportions were expressed in the form of $n(n \%)$, while continuous variables were expressed as mean (standard deviation).

Crude and adjusted odd ratios (ORs) were estimated using simple and multiple logistic regression models respectively. Intention for positive recommendation of the Master degree was associated with an initial dataset of demographic variables (age, sex, and marital status), educational status and background (first degree obtained, University degree, other Master/PhD, Master Program followed), working status (before and after graduation, private or public sector, type of contract, work consistency with Master/PhD, looking for work/seeking work), income increase and total satisfaction score using simple logistic regression models.

Multivariate analyses of intention for positive recommendation of the Master degree was examined by both enter and backward selection multiple regression models. The initial dataset of independent variables include those which result in p-values less than 0.200 from simple logistic models. The mentioned dataset includes sex, age, marital status, first degree obtained, work consistency first degree, work consistency Master/PhD, University or Technical Institution Degree, looking for a job/seeking work and Satisfaction Total Score. IBM SPSS Statistics 20.0 was used for analysis and a level of significance was set at 0.05 . 


\section{Results}

Characteristics of the sample and description of work status are presented below in Table 1.

Table 1. Demographics, work and study characteristics of participants in the survey.

\begin{tabular}{llll}
\hline Sex & $\mathrm{N}(\%)$ & Marital Status & $\mathrm{N}(\%)$ \\
\hline Female & $105(64.8 \%)$ & Married & $45(27.8 \%)$ \\
Male & $57(35.2 \%)$ & Not Married & $115(71.0 \%)$ \\
\hline Specialty & & & $10(6.2 \%)$ \\
\hline Doctor & $22(13.6 \%)$ & Health Administrators & $44(27.2 \%)$ \\
Nurse & $46(28.6 \%)$ & Administration and Finance & $11(6.8 \%)$ \\
Paramedical & $14(8.7 \%)$ & Social and Political Sciences & \\
Other & $14(8.6 \%)$ & & $156(96.3 \%)$ \\
\hline Work before & Master & Work after Master DEGREE & $6(3.7 \%)$ \\
DEGREE & & & \\
\hline Yes & $133(82.1 \%)$ & Yes & $19(11.7 \%)$ \\
No & $29(17.9 \%)$ & No & $143(88.3 \%)$ \\
\hline First Degree from & & ALREADY & HOLD \\
& & Master/PhD & $72(44.4 \%)$ \\
\hline University & $100(61.7 \%)$ & Yes & $83(51.2 \%)$ \\
Technical Institute & $59(36.4 \%)$ & No & \\
\hline Looking for work & & Income increase after Graduation & \\
\hline Yes & $50(30.9 \%)$ & Raise & Stable/Decrease \\
No & $112(69.1 \%)$ & & \\
\hline
\end{tabular}

It can be seen that females outnumber males (64.8\% vs 35.2\%). Among participants, concerning first degree, 82 $(50.9 \%)$ were in the category of Health Services and $65(37.2 \%)$ were graduates of Social and Economic Sciences. The majority (133 participants- $82.1 \%$ ) already had a job ( 91 in the public sector, while only 4 are part time - data in parenthesis not in Table). A significant percentage of the questioned Master graduates (50 persons- $30.9 \%$ ) were unemployed or looking for a job/seeking work at the time of the current research.

Table 2. Estimation of crude odd's ratio (OR) for proposing the Master degree

\begin{tabular}{lllllll}
\hline & Agree & $\mathrm{N}$ & $(\%)$ & \multicolumn{3}{c}{ 95\% C.I. OR } \\
& & OR & Lower & Upper & P \\
\hline Male (n=57) & $47(82.5 \%)$ & 0.49 & 0.19 & 1.27 & 0.144 \\
Age (1 year increase) & $33.5(6.6)$ & 1.06 & 0.97 & 1.15 & 0.196 \\
Married (45) & $42(93.3 \%)$ & 2.43 & 0.68 & 8.73 & 0.174 \\
First degree obtained & & & & & \\
Nurse (46) & $42(91.3 \%)$ & 1.70 & 0.54 & 5.38 & 0.369 \\
Paramedic(14) & $14(100.0 \%)$ & NE & NE & NE & NE \\
Health Administration (10) & $9(90.0 \%)$ & 1.30 & 0.16 & 10.81 & 0.811 \\
Administration and Finance (44) & $35(79.5 \%)$ & 0.40 & 0.15 & 1.05 & 0.064 \\
Social and Political Sciences (11) & $10(90.9 \%)$ & 1.45 & 0.18 & 11.98 & 0.730
\end{tabular}




\begin{tabular}{llllll} 
Other Specialty (14) & $14(100.0 \%)$ & $\mathrm{NE}$ & $\mathrm{NE}$ & $\mathrm{NE}$ & $\mathrm{NE}$ \\
Work before (133) & $116(87.2 \%)$ & 0.79 & 0.21 & 2.89 & 0.718 \\
private Sector (63) & $54(85.7 \%)$ & 0.86 & 0.31 & 2.38 & 0.768 \\
indefinite contract (86) & $76(88.4 \%)$ & 1.63 & 0.54 & 4.90 & 0.385 \\
full time (114) & $99(86.8 \%)$ & 0.55 & 0.07 & 4.54 & 0.579 \\
work consistency Degree (110) & $98(89.1 \%)$ & 2.27 & 0.71 & 7.22 & 0.166 \\
work consistency Master/PhD (66) & $66(90.4 \%)$ & 1.96 & 0.70 & 5.53 & 0.201 \\
Work after graduation (156) & $136(87.2 \%)$ & $\mathrm{NE}$ & $\mathrm{NE}$ & $\mathrm{NE}$ & $\mathrm{NE}$ \\
private Sector (62) & $53(85.5 \%)$ & 0.81 & 0.31 & 2.09 & 0.662 \\
indefinite contract (123) & $110(89.4 \%)$ & 2.12 & 0.61 & 7.29 & 0.235 \\
full time (144) & $126(87.5 \%)$ & $\mathrm{NE}$ & $\mathrm{NE}$ & $\mathrm{NE}$ & $\mathrm{NE}$ \\
work consistency Degree (139) & $123(88.5 \%)$ & 2.37 & 0.69 & 8.14 & 0.172 \\
work consistency Master/PhD (106) & $92(86.0 \%)$ & 0.90 & 0.32 & 2.49 & 0.833 \\
Increase income (72) & $64(88.9 \%)$ & 1.35 & 0.52 & 3.52 & 0.536 \\
University Degree (100) & $84(84.0 \%)$ & 0.38 & 0.12 & 1.20 & 0.100 \\
Other Master/PhD (19) & $17(89.5 \%)$ & 1.22 & 0.26 & 5.75 & 0.798 \\
Yes Seeking work (50) & $40(80.0 \%)$ & 0.39 & 0.15 & 1.01 & 0.053 \\
Master Program UoP (89) & $85(95.5 \%)$ & 1.0 & & & \\
Master Program NKUA (53) & $46(86.8 \%)$ & 0.89 & 0.33 & 2.38 & 0.816 \\
Master Program UoC (20) & $20(100.0 \%)$ & $\mathrm{NE} *$ & $\mathrm{NE}$ & $\mathrm{NE}$ & $\mathrm{NE}$ \\
Satisfaction Total Score & $134.7(18.3)$ & 1.09 & 1.05 & 1.13 & $<0.001$ \\
\hline NE : Not esimad & & & & & \\
\hline
\end{tabular}

* NE : Not estimated

Each of the variables presented in Table 2 have been checked for association with WoMC. Odd's ratios (OR's) with $95 \% \mathrm{CI}$ were used for estimating the previously mentioned associations. Satisfaction Total Score variable, 1.09 (10.5-1.13), is presenting association with WoMC $(\mathrm{p}<0.05)$. At 0.100 level "Seeking Work" has a tendency for negative effect $0.39(0.15-1.01)$ on WoMC, and the existence of a University degree $0.38(0.12-1.20)$ - as opposed to a Technical University degree. Other variables presenting association at 0.100 levels with WoMC is the degree of administration and finance departments 0.40 (0.15-1.05).

Variables which present a $\mathrm{p}<0.200$ in Table 2, were included in the final multiple logistic model with enter (Model 1) and backward (Model 2) selection.

Table 3. Estimation of odd's ratio (OR) for proposing the Master Program based on enter (Model 1) and backward (Model 2) multiple logistic regression

\begin{tabular}{llllll}
\hline Model 1 & & \multicolumn{3}{c}{$95 \%$ CI } \\
\hline & & $\mathrm{p}$ & OR & Lower & Upper \\
\hline Male & 0.799 & 0.80 & 0.14 & 4.59 \\
Age & 0.449 & 0.93 & 0.79 & 1.11 \\
Marital Status=Married & 0.675 & 0.65 & 0.08 & 4.97 \\
Degree of Administration and Finance & 0.281 & 0.37 & 0.06 & 2.27 \\
Work consistency Degree (Before Master) & 0.995 & 1.01 & 0.09 & 11.46 \\
Work consistency PhD/Master & 0.600 & 1.67 & 0.25 & 11.21 \\
Work consistency Degree (After Master) & 0.427 & 0.27 & 0.01 & 7.02 \\
& University Degree & 0.436 & 0.42 & 0.05 & 3.72
\end{tabular}




\begin{tabular}{llllll} 
& Seeking Work / Looking for a Job & 0.023 & 0.06 & 0.01 & 0.68 \\
& Satisfaction Total Score & $<0.001$ & 1.13 & 1.06 & 1.21 \\
\hline $\begin{array}{l}\text { Model } \\
2^{*}\end{array}$ & & & & $95 \%$ CI & \\
\hline & Seeking Work / Looking for a Job & 0 & OR & Lower & Upper \\
\hline & Satisfaction Total Score & 0.012 & 0.12 & 0.02 & 0.63 \\
& $<0,001$ & 1.11 & 1.06 & 1.17
\end{tabular}

* Initial dataset of variables were: sex, age, marital status, first degree, work consistency degree (before and after the Master degree), work consistency Master, University Degree, Looking For a Job/Seeking Work, Satisfaction Total Score.

Both approaches shown in Table 3, conclude that Total Satisfaction score has a positive effect on proposing the Master Program (OR: 1.11, 95\%CI: 1.06-1.17), while being unemployed or looking for a job/seeking work has a negative impact (OR: $0.12,95 \% \mathrm{CI}: 0.02-0.63$ ) as shown from the backward selection model.

\section{Discussion}

Students' and graduates' Word of Mouth intention about the course they have attended to others is one of the parameters explored in various studies. It often constitutes an element of surveys either on course experience satisfaction or on course selection processes adopted by prospective students (Moogan et al., 1999, Ivy, 2001, Cubillo et al., 2006, Arambewela et al., 2006) It can be formulated as a statement or a question about their willingness to recommend the course to others. Furthermore, useful conclusions can be extracted when correlating their intention with demographic, educational, vocational and satisfaction characteristics contributing both to the sustainability of institutions and in quality amendment of the provided course.

It is the first time that Greek graduates have been surveyed concerning their intention for positive WoMC. Word of Mouth Communication (WoMC) of Master graduates was investigated regarding satisfaction of the course and how different variables of academic and educational quality affect it. Word of Mouth Communication is described as an element of consumerist services studies, thus it was approached under the prism that students and graduates are mostly partners more than clients of Universities (Clayson \& Haley, 2005, Gruber et al., 2010). This applies to Greek Masters that are organized by small or medium sized Institutions, compared to the global education environment, offering yearly one or two classes of twenty to twenty five students. In terms of available welfare facilities and infrastructure there is not actually the concept of "campus" while most modules are delivered in Greek. Master costs are totally or partially subsidized by state funds and European grants supporting the public character of education in Greece (Master students from University of Piraeus pay fees). Another deficit concerns the lack of established alumni networks that deprives mutual communication between graduates and institutions which could be beneficial both in terms of employability and the career achievement of former students. Based on the above elements one could conclude that until present the Greek Masters operate in a protected environment far from international competition and this can be reflected among other matters by the absence of foreigner students joining them. Nevertheless it is believed that the competencies of the available research and academic staff along with the current curriculum structure, after selected additions, could potentially formulate Master courses of international interest.

Both students and universities are responsible for the experience of learning in terms of quality and satisfaction. Therefore interaction and satisfaction measurements are the means for receiving feedback from the service users and to find deficiencies but also to take action and to meet the current and forthcoming educational needs of students. Furthermore, educational services of high quality lead to quality graduates and this indirectly gives a positive impact on HEIs (Rajab et al., 2011).

The results revealed that overall satisfied Health Management Master Graduates of Greek universities with positive perceptions towards the educational service they have used, subsequently adopt positive WoMC. Findings about the first question that was surveyed, agree with previous research where results confirm that high quality in educational services and satisfaction as a concept affect positive WoMC intention (DeRuyter, Bloemer, and Pascal, 1997, Zins, 2001, Jiewanto et al., 2012) and as a consequence satisfied students and graduates can attract new students through their positive WoMC (Wiers-Jenssen et al., 2002, Mavondo et al., 2004, C. Schertzer \& S. Schertzer, 2004, Marzo-Navarro et al., 2005a, 2005b, Helgesen \& Nesset, 2007). Perceived satisfaction and quality, which in literature are often used as synonymous, (Bitner \& Hubert, 1994, Cronin, 
Brady, and Hult, 2000) increase student positive WoMC intention which is beneficial for the sustainability of Higher Education Institutions (Jiewanto et al., 2012). As Guolla (1999) claimed highly satisfied students would engage in positive WoMC such as recommending the Institution or the course and concerning fiscal extension this proposal can be directly related to fundraising (Elliott \& Shin, 2002, Gruber et al., 2010).

An interesting research finding about the influence of unemployment and insecure vocational status on adopting negative WoMC derived after exploring the second research question posed. The research agrees with previous studies where unfulfilled personal expectations of vocational rehabilitation and evolution can lead to a sense of dissatisfaction and formulate negative WoMC towards a course. Since the marketability of degrees is of vital importance to prospective students (Arambewela et al., 2006), employability after graduation formulates positive or negative WoMC affecting the fame and the image of an Institution. Interpreting the results, it can be assumed that employment prospects for the Master graduates surveyed remain to a great degree poor though comparing to their expectations.

Postgraduate students invest time and funds, to ameliorate among other factors their future career prospects. Therefore they comment negatively to others regarding the Master course they selected if they are unemployed or remain in a stable employment position regarding their career after graduation. As Moogan (2011) has noticed, potential future career advancement is of major importance when deciding whether or not to continue studying at a postgraduate level, along with employment prospects when attending a course (Moogan, Baron, and Harris 1999). Binsardi and Ekwulugo, (2003) and Cubillo et al., (2006) have also argued that employability prospects are an important factor in personal motivation for a candidate when selecting to attend a course. While approaching education as a service, the fulfillment of individual's needs and expectations constitutes a core element leading to course satisfaction (Marra, 1989, Rajab et al., 2011).

As far as is known, for the rest of the variables, association with word of mouth intention was checked and there are no comparable data or relative studies in Greece. However, findings of student surveys have indicated that career prospects after graduation and the links of the University with business (Tsinidou, Gerogiannis, and Fitsilis, 2010), the finding of a job relevant to the study field (Mousouli, Florou, Nikitopoulou, and Goudas, 2003) and the fulfilment of career expectations (Kotivas, Tsipa, and Tsipas, 2005) are of major importance for Greek students regarding their course experience. There has been no further investigation on how these concepts affect their word of mouth intention.

Care should be exercised when comparing the findings of the present study to others from institutions that operate at an international level or under a different educational context. As previously mentioned the Greek educational system has lots of specifics and operates under the surveillance of central state authorities and limited interaction with private sector strategies.

\subsection{Limitations of the Study}

One limitation of the present study is that the variable Total Experience Satisfaction which proved to be important for adopting positive WoMC is based on graduates self-reporting. Nevertheless, previous studies indicate that self-reports are indeed acceptable as a means of measuring satisfaction (Pike, 1996, Di Biase, 2004, Rhodes \& Nevill, 2004, Richardson, 2005, Garcia-Aracil, 2009). Another limitation is that the perceptions were surveyed only of those who have successfully completed their Master degree. Care must be exercised when comparing current results with relevant surveys from the UK and Australian questionnaires (on which the current survey tool was based) since their graduates are usually questioned close to graduation time. Graduates were surveyed two to four years after graduation which may have an impact in the formulation of WoMC. However, this helps the research to have a better view regarding the utilization of skills and knowledge acquired by graduates in the market. Graduates have the time to test if the master course they attended ameliorated their career prospects and the chance to find the job they wanted. This way they adopt WoMC that corresponds to the real impact of the Master Degree and the qualifications acquired for their career, and not for the one they believed when they decided to attend it.

\section{Conclusion}

Satisfaction and career prospects are two crucial factors for the formulation of positive WoMC among Greek Master graduates. WoMC is important for an Institution to maintain its competitive position and to benefit from that by using it as an indicator to improve its course content. Furthermore findings of positive word of mouth intention can initially support the hypothesis that there is a match between students' employment expectations and the overall curricula quality and design. 
Greek Masters need to develop strategies that create a strong institutional reputation and confidence in the course quality they offer and to communicate it, amongst other ways, through alumni channels. Quality assurance is a secure path to remaining competitive in international educational market and its implementation will empower Greek HEIs to attract prospective international students, who are willing to pay fees for a service of high quality. The sustainability of the Institutions will depend to great extent on the adoption of procedures that can guarantee satisfied graduates, strong brand name, reputation and curricula quality.

\section{Implications for Action}

Stakeholders and interested parties in the Greek education system can utilize measurements on word of mouth referral of graduates as an effective recruitment instrument for Institutions and a valuable indicator. Under that perspective, they could act in two directions. Managers of each Greek Master course should survey the real skill and qualification needs of graduates in terms of employability. Results based on systematic recording of employability rates and satisfaction scores among graduates can be a first step for Greek HEIs to review and modernize their curricula.

Additionally the establishment of alumni unions and the connection of HEIs with both private and public enterprises will empower the link between HEI management boards and the employment conditions outside the borders of a campus. It will provide a valuable update about present needs and future changes in the market concerning new skills and qualifications that HEIs should include in the offered curricula. Periodical interviews of graduates that have found a job should be of first priority, since they can act as valuable information sources and tools (Nemko, 2008, Moogan, 2011). HEIs can also communicate through the experiences of successful and satisfied graduates with future candidates to meet both their expectations and offer courses which lead to skill acquisition.

Regarding course experience satisfaction measurements, the findings can be seen as a motive for the implementation of new assessment procedures by The Greek Quality Assurance and Accreditation system for Greek HE Institutions. The "Hellenic Quality Assurance Agency" for Higher Education has been established by No3374/2005 law relatively recently to implement course assessment procedures in HEIs. In terms of curricula reform as an outcome based on survey, results have demonstrated no significant progress so far. It mostly records aspects of academic quality by interviewing master participants during the courses. Only fragmentary evaluations of teaching and curriculum quality done by the students have so far been recorded in most of the Greek HEIs. Course evaluation stops after graduation meaning that career and employability changes of former students have not been tracked. It is here suggested that data collection and graduates surveys should continue, after students leave the Institution to join the market, through the use of a proper survey instrument. In other words, assessment procedures need to be enriched by new research fields relative to career evolution, vocational mobility and changes in the demands of employment.

\section{References}

Arambewela, R., Hall, J., \& Zuhair, S. (2006). Postgraduate International Students from Asia: Factors Influencing Satisfaction. Journal of Marketing for Higher Education, 15(2), 105-127. http://dx.doi.org/10.1300/J050v15n02_05

Arndt, J. (1967). Role of Product-Related Conversations in The Diffusion of a New Product. Journal of Marketing Research, 4, 291-295.

Bansal, H. S., \& Voyer, P. A. (2000). Word-of-Mouth Processes Within a Services Purchase Decision Context. Journal of Service Research, 3(2), 166-177. http://dx.doi.org/10.1177/109467050032005

Binsardi, A., \& Ekwulugo, F. (2003). International marketing of British education: Research on the students' perception and the UK market penetration. Marketing Intelligence \& Planning, 21(5), 318-327. http://dx.doi.org/10.1108/02634500310490265

Bitner, M. J., \& Hubert, A. R. (1994). Encounter satisfaction versus overall satisfaction versus quality. In R. T. Rust, \& R. L. Oliver (Eds.), Service Quality: New Directions in Theory and Practice (pp. 72-94). Sage Publications, Thousand Oaks, CA.

Bruce, G., \& Edgington, R. (2008). Factors influencing word-of-mouth recommendations by MBA students: An examination of school quality, educational outcomes and value of the MBA. Journal of Marketing for Higher Education, 18(1), 79-101. http://dx.doi.org/10.1080/08841240802100303

Clayson, D. E., \& Haley D. A. (2005). Marketing models in education: Students as customers, products, or partners. Marketing Education Review, 15(1), 1-10. 
Cronin, J. J., \& Taylor, A. S. (1992). Measuring service quality: Re-examination and extension. Journal of Marketing, 56(3), 56-68. Retrieved from: http://www.jstor.org/stable/1252296

Cronin, J. J., Brady, K. M., \& Hult, M. T. (2000). Assessing the effects of quality, value and customer satisfaction on consumer behavioral intentions in service environments. Journal of Retailing, 76(2), 193-218. http://dx.doi.org/10.1016/S0022-4359(00)00028-2

Cubillo, J. M., Sánchez, J., \& Cerviño, J. (2006). International students' decision-making process. International Journal of Educational Management, 20(2), 101-115. http://dx.doi.org/10.1108/09513540610646091

Dabholkar, P., Thorpe, D. I., \& Rentz, J. Q. (1996). A Measure of Service Quality for Retail Stores. Journal of the Academy of Marketing Science, 24(1), 3-16. http://dx.doi.org/10.1007/BF02893933

De Ruyter, K., Bloemer, J., \& Pascal, P. (1997). Merging Service Quality and Service Satisfaction: An Empirical Test of an Integrative Model. Journal of Economic Psychology, 18(4), 187-406. http://dx.doi.org/10.1016/S0167-4870(97)00014-7

Di Biase, D. (2004). The impact of increasing enrolment on faculty workload and student satisfaction over time. Journal of Asynchronous Learning Networks, 8(2), 45-60.

Elliott, K. M., \& Shin, D. (2002). Student Satisfaction: An Alternative Approach to Assessing this Important Concept. Journal of Higher Education Policy and Management, 24(2), 197-209. http://dx.doi.org/10.1080/1360080022000013518

Garcia-Aracil, A. (2009). European graduates' level of satisfaction with higher education. Higher Education, 57(1), 1-21. http://dx.doi.org/10.1007/s10734-008-9121-9

Gruber, T., Reppel, A., \& Voss, R. (2010). Understanding the characteristics of effective professors: The student's perspective. Journal of Marketing for Higher Education, 20(2), 175-190. http://dx.doi.org/10.1080/08841241.2010.526356

Guolla, M. (1999). Assessing the teaching quality to student satisfaction relationship: Applied Customer satisfaction research in the classroom. Journal of Marketing Theory and Practice, 7(3), 87-97.

Hartman, E. D., \& Schmidt, L. S. (1995). Understanding student/alumni satisfaction from a consumer's perspective: The effects of institutional performance and program outcomes. Research in Higher Education, 36(2), 197-217. http://dx.doi.org/10.1007/BF02207788

Harvis, B., \& Voyer, P. A. (2000). Word of Mouth processes within a services purchase decision context. Journal of Service Research, 3(2), 166-177. http://dx.doi.org/10.1177/109467050032005

Helgesen, Ø., \& Nesset, E. (2007). What accounts for students' loyalty? Some field study evidence. $\begin{array}{llll}\text { International Journal of Educational } & \text { Management, } & \text { 21(2), }\end{array}$ http://dx.doi.org/10.1108/09513540710729926

Ivy, J. (2001). Higher education institution image: A correspondence analysis approach. The International Journal of Educational Management, 15(6), 276-282. http://dx.doi.org/10.1108/09513540110401484

Ivy, J. (2008). A new higher education marketing mix: The 7Ps for MBA marketing. International Journal of Educational Management, 22(4), 288-99. http://dx.doi.org/10.1108/09513540810875635

Jiewanto, A., Laurens, C., \& Nelloh, L. (2012). Influence of Service Quality, University Image, and Student Satisfaction toward WOM Intention: A Case Study on Universitas Pelita Harapan Surabaya. Procedia Social and Behavioral Sciences, 40, 16-23. http://dx.doi.org/10.1016/j.sbspro.2012.03.155

Kotivas, K., Tsipa, M., \& Tsipas, D. (2005). The development and implementation of a pilot internal evaluation procedure for postgraduate engineering courses. World Transactions on Engineering and Technology Education, 4(1), 83-86.

Kotsifos, V., Alegakis, A., \& Philalithis, A. (2012). Health care management courses in Greek universities: A first attempt to establish factors affecting satisfaction. Quality Assurance in Education, 20(2), 139-152. http://dx.doi.org/10.1108/09684881211219389

Marra, T. R. (1989). Improved Customer Care and Service. New York, NY: McGraw-Hill.

Marzo-Navarro, M., Pedraja-Iglesias, M., \& Rivera-Torres, M. P. (2005a). Measuring customer satisfaction in summer courses. Quality Assurance in Education, 13(1), 53-65. http://dx.doi.org/10.1108/09684880510578650 
Marzo-Navarro, M., Pedraja-Iglesias, M., \& Rivera-Torres, M. P. (2005b). A new management element for universities: Satisfaction with the offered courses. International Journal of Educational Management, 19(6), 505-526. http://dx.doi.org/10.1108/09513540510617454

Mavondo, F. T., Tsarenko, Y., \& Gabbott, M. (2004). International and local student satisfaction: Resources and capabilities perspective. Journal of Marketing for Higher Education, 14(1), 41-60. http://dx.doi.org/10.1300/J050v14n01_03

Mazzarola, T., Soutarb, G. N., \& Theina, V. (2001). Critical Success Factors in the Marketing of an Educational Institution: A Comparison of Institutional and Student Perspectives. Journal of Marketing for Higher Education, 10(2), 39-57. http://dx.doi.org/10.1300/J050v10n02_04

Moogan, Y. J. (2011). Can a higher education institution's marketing strategy improve the student-institution match? International Journal of Educational Management, 25(6), 570-589. http://dx.doi.org/10.1108/09513541111159068

Moogan, Y. J., Baron, S., \& Harris, K. (1999). Decision Making Behavior of potential Higher Education Students. Higher Education Quarterly, 53(3), 211-228. http://dx.doi.org/10.1111/1468-2273.00127

Mousouli, M., Florou, S., Nikitopoulou, C., \& Goudas, M. (2004). Evaluation of Physical Education and Sport Sciences Students' Satisfaction with their Studies. Inquiries in Sport \& Physical Education, 2(1), 73-80 (in Greek).

Murray, K. B. (1991). A Test of Service Marketing Theory: Consumer Information Acquisition Activities. Journal of Marketing, 55(1), 10-15.

Murray, K. B., \& Schlacter, J. L. (1990). The Impact of Services versus Goods on Consumers' Assessment of Perceived Risk and Variability. Journal of the Academy of Marketing Science, 18(1), 51-65.

Naik, C. N. K., Gantasala S. B., \& Prabhakar, G. V. (2010). (SERVQUAL), Customer Satisfaction and Behavioral Intentions in Retailing. European Journal of Social Sciences, 17(2), 200-213.

Parasuraman, A., Berry, L. L., \& Zeithaml, V. A. (1988). SERVQUAL: a multiple-item scale for measuring consumer perceptions of services quality. Journal of Retailing, 64(1), 12-40.

Pike, G. R. (1996). Limitations of using students' self reports of academic development as proxies for traditional achievement measures. Research in Higher Education, 37(1), 89-114. http://dx.doi.org/10.1007/BF01680043

Rajab, A., Panatik, S. A, Rahman, A., Rahman, H. A., Shaari, R., \& Saat, M. (2011). Service Quality in a Research University: A Post-Graduate Perspective. Procedia - Social and Behavioral Sciences, 29, 1830-1838. http://dx.doi.org/10.1016/j.sbspro.2011.11.431

Rhodes, C., \& Nevill, A. (2004). Academic and social integration in higher education: A survey of satisfaction and dissatisfaction within a first-year education studies cohort at a new university. Journal of Further and Higher Education, 28(2), 179-93. http://dx.doi.org/10.1080/0309877042000206741

Richardson, T. E. J. (2005). Instruments for obtaining student feedback: A review of the literature. Assessment and Evaluation in Higher Education, 30(4), 387-415. http://dx.doi.org/10.1080/02602930500099193

Schertzer, C. B., \& Schertzer, S. M. B. (2004). Student satisfaction and retention: A conceptual model. Journal of Marketing for Higher Education, 14(1), 79-91. http://dx.doi.org/10.1300/J050v14n01_05

Spreng, R. A., \& Mackoy, R. D. (1996). An Empirical Examination of a Model of Perceived Service Quality and Satisfaction. Journal of Retailing, 72(2), 201-214.

Tsinidou, M., Gerogiannis, V., \& Fitsilis, P. (2010). Evaluation of the factors that determine quality in higher education: An empirical study. Quality Assurance in Education, 18(3), 227-244. http://dx.doi.org/10.1108/09684881011058669

Wiers-Jenssen, J., Stensaker, B., \& Grogaard, J. B. (2002). Student satisfaction: Towards an empirical deconstruction of the concept. Quality in Higher Education, 8(2), 183-195. http://dx.doi.org/10.1080/1353832022000004377

Zeithaml, V. A. (1981). How Consumer Evaluation Processes Differ between Goods and Services. In J. H. Donnelly, \& W. R. George, (Eds.), Marketing of Services (pp. 186-90). American Marketing Association, Chicago IL. 
Zins, A. H. (2001). Relative attitudes and commitment in customer loyalty models. International Journal of Service Industry Management, 12(3), 269-294. http://dx.doi.org/10.1108/EUM0000000005521

\section{Copyrights}

Copyright for this article is retained by the author(s), with first publication rights granted to the journal.

This is an open-access article distributed under the terms and conditions of the Creative Commons Attribution license (http://creativecommons.org/licenses/by/3.0/). 